\title{
Aerosol distribution over Brazil with ECHAM-HAM and CAM5-MAM3 simulations and its comparison with ground-based and satellite data
}

\author{
Débora Souza Alvim ${ }^{a}$, , Jayant Pendharkar ${ }^{a}$, Vinicius Buscioli Capistrano a, \\ Ariane Frassoni ${ }^{a}$, Diego Pereira Enoré ${ }^{a}$, Otacílio Leandro de Menezes Neto a, \\ Enver Ramirez Gutierrez ${ }^{a}$, Ayantika Dey Choudhury ${ }^{\mathrm{c}}$, Paulo Yoshio Kubota ${ }^{\text {, }}$ \\ Josiane da Silva ${ }^{a}$, Sergio Machado Correa ${ }^{\text {b }}$, Paulo Nobre ${ }^{a}$, Silvio Nilo Figueroa ${ }^{\text {a }}$ \\ ${ }^{a}$ Center for Weather Forecasting and Climate Studies, and Earth System Science Center-CCST, National Institute for Space Research, Cachoeira Paulista, SP, \\ Brazil \\ ${ }^{\mathrm{b}}$ Rio de Janeiro State University, Faculty of Technology, Resende, RJ, Brazil \\ ${ }^{\mathrm{c}}$ Indian Institute of Tropical Meteorology, Pune, 411008, India
}

\section{A R T I C L E I N F O}

Article history:

Received 6 June 2016

Accepted 17 January 2017

Available online 26 January 2017

\section{Keywords:}

Aerosol optical depth

Climate change

Model assessment

Aerosol Brazil

ECHAM-HAM and CAM5-MAM3 models

\begin{abstract}
A B S T R A C T
The accurate representation of the impacts of natural and anthropogenic aerosols in the climate system presents a challenge in General Circulation Models. This paper analyzes the performance of the aerosol component of two Atmospheric General Circulation Models (AGCM): the Europe Centre Hamburg Model - Hamburg Aerosol Model (ECHAM-HAM), and the Community Atmosphere Model - Modal Aerosol Model (CAM5-MAM3) and their comparison with aerosol observations. We analyzed the spatial distribution of aerosols over Brazil represented in terms of the aerosol optical depth (AOD) simulated by these models. The model results are compared to measurements from Aerosol Robotic Network (AERONET) ground station, and satellite observations provided by the Moderate Resolution Imaging Spectroradiometer (MODIS). While both the models provide AODs at $550 \mathrm{~nm}$, only HAM provides the Angström exponent that is compared with AERONET measurements. The comparison between the model simulations and the satellite observations of AOD show that the models can reproduce the spatial and temporal distributions, however models underestimate AOD for the four cities and for almost every South American continent during all seasons. During the dry season, characterized by intense biomass burning, CAM5-MAM3 shows inconsistent, but comparatively better results that ECHAM-HAM, with negative biases over Northern and Northeastern regions of Brazil. The Angström parameter is reasonably reproduced by ECHAM-HAM, except for Cuiabá, indicating that the particle size distribution is correctly represented in most cities.
\end{abstract}

๑) 2017 Turkish National Committee for Air Pollution Research and Control. Production and hosting by Elsevier B.V. All rights reserved.

\section{Introduction}

Atmospheric aerosols play an important role in global and regional climate systems by influencing the energy balance of the atmosphere and Earth's surface, thus modifying the hydrological cycle (Ramanathan et al., 2005). Anthropogenic burnings, which occur mostly in tropical areas of the planet, are important source of

\footnotetext{
* Corresponding author.

E-mail address: deborasalvim@gmail.com (D.S. Alvim).

Peer review under responsibility of Turkish National Committee for Air Pollution Research and Control.
}

greenhouse gases and aerosols to the atmosphere (Artaxo et al., 2002; Freitas et al., 2009). Hundreds of thousands of fires occur during the winter months over South America, mainly in cerrado and forest ecosystems, being predominantly associated with agricultural practices. These fires occur mainly in the regions of the Amazon and Central Brazil, but due to the atmospheric transport of their emissions they produce a spatial distribution of smoke over an extensive area, around 4-5 million $\mathrm{km}^{2}$, much larger than the area where they are concentrated (Freitas et al., 2009).

During the combustion of biomass, gases are emitted into the atmosphere, including some greenhouse gases and tropospheric ozone precursors, as well as aerosol particles that interact 
efficiently with solar radiation and affect the microphysical processes and dynamics to cloud formation and air quality. The effects of these emissions therefore exceed the local scale and affect regionally the composition and physical and chemical properties of the atmosphere over South America and over the surrounding oceanic areas, with potential impact on a global scale. Changes in the chemical composition of the atmosphere related to air quality are also a matter of increasing concern. Populations living on both the planet's megacities and in regions of occurrence of high burnings are subject to an increasing number of days when air quality degrades to levels below those recommended by the World Health Organization and provided for in legislation covering Environmental impact of different countries. Among the pollutants with the greatest impact on public health, the low particulate matter of $2.5 \mu \mathrm{m}\left(\mathrm{PM}_{2.5}\right)$ and ozone $\left(\mathrm{O}_{3}\right)$ are noteworthy.

The emission of large quantities of primary aerosols resulting from the biomass burning for clearing areas of agriculture or pasture over Brazil has caused great environmental damage not only at the surface, but also in the atmosphere. Partially oxidized organic particles and black carbon (BC) are also emitted and they are effective in scattering and absorbing solar radiation, which has been known as the direct effect of aerosols in the atmosphere (Rosenfeld et al., 2008). Numerical simulations performed by Jacobson (2001) on the evolution of the chemical composition of aerosols suggest that the radiative forcing of $\mathrm{BC}$ is higher than previous calculations, and may balance the cooling effect of other anthropogenic aerosols. The computed value of the direct radiative forcing for $\mathrm{BC}$ is $0.55 \mathrm{~W} \mathrm{~m}^{-2}$, making it the second most important anthropogenic component in global warming after $\mathrm{CO}_{2}$ in terms of direct radiative forcing.

The solar radiation that reaches the Earth's surface is reduced and the balance in the surface-atmosphere system is modified due to scattering and absorption in the aerosol layer by carbonaceous compounds (Santanna, 2008). Studies in regions of fires in Brazil (Procópio and Artaxo, 2003), specifically in sites located at Alta Floresta (Mato Grosso state), and Ji-Paraná (Rondônia state), showed that $20 \%$ of incoming solar radiation is absorbed or reflected by the aerosols from biomass burning. It is responsible for the reduction of $1 / 3$ of the direct radiation that reaches the surface, and a seven-fold increase in the diffuse radiation. A typical aerosol plume resulting from biomass burning can absorb up to $400 \mathrm{~W} \mathrm{~m}^{-2}$, by subtracting $30 \%$ of the radiation at the visible range, which can interfere with photosynthesis rates. According to Hobbs et al. (1997), for the regions of biomass burning in Brazil, the direct radiative forcing by atmospheric aerosol particles is significant due to the high values of optical depth over large regions.

Studies on the impact of aerosols on climate rely on the correct representation of particle size, composition and origin, in addition to their spatial and temporal variability (Hansen et al., 2007). The modeling of aerosols that requires transformation process studies, in situ measurements and satellite observations, are in substantial progress (Climate Change Science Program, 2009), however some discrepancies pertaining to the magnitude and the spatial distribution of aerosols in climate models remain obscure (Ghan and Schwartz, 2007). Therefore, the aerosols distribution evaluation in climate models is essential to quantify the possible effects in future climate (Sanap et al., 2014).

The objective of this paper is to evaluate the performance of the aerosol component of the European Centres' - Hamburg Aerosol Model (ECHAM6-HAM) developed at Max Planck Institute for Meteorology, and Community Atmosphere Model - Modal Aerosol Model (CAM5-MAM3) developed at the National Center Atmospheric Research (NCAR) against the available aerosol observations for Brazil. The simulated aerosol optical depth (AOD) is compared with measurements from Aerosol Robotic Network (AERONET) ground station, and satellite observations provided by the Moderate Resolution Imaging Spectroradiometer (MODIS). The sites and the period chosen for this study were defined on the availability of AOD database from the AERONET stations. In Brazil, though there are 27 AERONET stations monitoring aerosols in the atmospheric column, only a small number of them provide complete time series.

The paper is organized as follows. Section 2 provides a brief description of the two models confining to the scope of the present study followed by the details on the ground-based and satellite data and finally, the experimental configurations for the two models. The results are presented in Section 3 followed by the conclusions in Section 4.

\section{Models, observational data and experiment design}

\subsection{Models}

\subsubsection{ECHAM6-HAM2.1 model}

The ECHAM6-HAM2.1 is a sixth-generation climate model that represents the dynamics, microphysics, transport, and radiative feedbacks of the main atmospheric aerosols: sulfate, BC, primary organic aerosol (POA), and secondary organic aerosol (SOA), sea salt and mineral dust (O'Donnell et al., 2011, Giorgetta et al., 2013.). Emissions in this model are calculated on-line for dust, along with sea salt and dimethyl sulfide (DMS), while they are prescribed for other natural and anthropogenic emissions. HAM2.1 calculates the optical depth, number concentration and mass concentration of the aerosols. The model takes a modal approach for calculating dynamically the optical properties of aerosols mode by mode assuming different compositions in the same mode to be in an internally mixed state.

The Mie-scattering size parameter and volume-averaged refractive indices for each mode are derived from the chemical composition and particle size. The derived parameters are then passed on to a look-up table that is based on Mie-theory assuming 24 spectral bands for shortwave and 16 bands for long-wave radiation. The extinction cross-section $\varphi$, single scattering albedo $\omega$, and asymmetry parameter $\gamma$ were obtained from the look-up tables that are then re-mapped to the bands of the ECHAM radiation scheme (Stier et al., 2005). The effects of aerosols on radiation are considered for both short and long waves; BC refractive indices were updated by Stier et al. (2007). Synthesized parameters are then derived for the calculation of radiative transfer, assuming external mixing of different modes.

\subsubsection{CAM5-MAM3 model}

A modal aerosol model (MAM) (Liu et al., 2012) of the National Center for Atmospheric Research (NCAR) Community Atmosphere Model version 5 (CAM5) represents the dynamic of the main atmospheric aerosols in CAM5, with seven lognormal modes (MAM7), and with three lognormal modes (MAM3). In this work, CAM5-MAM3 version is used which includes sulfate aerosols (SU), $\mathrm{BC}$, primary organic aerosol (POA), dust (DU), sea salt (SS) and secondary organic aerosols (SOA). The Rapid Radiative Transfer Model for GCMs (RRTMG) radiation parameterizations scheme is used in CAM5 (Iacono et al., 2008). Aerosol radiative effects are treated in RRTMG through the specification of their optical properties within each spectral interval. Aerosol optical properties are parameterized in terms of wet refractive index and wet surface mode radius according to Ghan and Zaveri (2007), except that volume-mixing rule is used to calculate the volume mean wet refractive index for mixtures of insoluble and soluble particles. Refractive indices for most aerosol components are taken from OPAC (Hess et al., 1998), but for black carbon the value $(1.95,0.79 \mathrm{i})$ from Bond and Bergstrom (2006) are used. 


\subsection{Observational data}

\subsubsection{Ground-based measurements}

Observational AOD and Angström parameter data (level 2.0) were obtained from the AERONET measurements for four locations in Brazil (see Fig. 1): São Paulo $\left(23^{\circ} \mathrm{S} 46^{\circ} \mathrm{W}\right)$, Cuiabá $\left(15^{\circ} \mathrm{S} 56^{\circ} \mathrm{W}\right)$, Rio Branco $\left(9^{\circ} \mathrm{S} 67^{\circ} \mathrm{W}\right)$ and Alta Floresta $\left(9^{\circ} \mathrm{S} 56^{\circ} \mathrm{W}\right)$. These stations were chosen because they contain the most complete AERONET dataset (2001-2006). Fig. 1 shows the four Brazilian regions (South, Southeast, Midwest, Northeast and North). AOD is a key parameter in aerosol measurements; it provides a measure to quantify the amount of aerosols present in the atmospheric column (Holben et al., 2001). AERONET measurements are obtained using solar photometers and are site specific. The measurements are performed at various wavelengths and are timed at intervals of $15 \mathrm{~min}$ with an accuracy of $\pm 0.015 \mathrm{~s}$. AERONET products are available in different levels of processing: level 1.0 (raw data), level 1.5 (automated cloud tracking data), and level 2.0 (data with guaranteed quality). In this work, we have used level 2.0 data to eliminate cloud interference and ensure data quality.

Measurements of AOD from the AERONET stations are carried out at $500 \mathrm{~nm}$, while MODIS (satellite) products and the data simulated by ECHAM-HAM and CAM5-MAM3 models are at available at $550 \mathrm{~nm}$. AERONET AODs at $550 \mathrm{~nm}$ are computed using the Angström exponent available from the same instrument at
$440 \mathrm{~nm}-675 \mathrm{~nm}$ using the equation:

$\tau 2=\tau 1 / e^{\left[-\alpha \ln \left(\frac{\lambda 1}{\lambda 2}\right)\right]}$

where $\tau 2$ is the AOD at $550 \mathrm{~nm}, \tau 1$ is the AOD at $500 \mathrm{~nm}, \alpha$ is the Angström exponent between 440 and $675 \mathrm{~nm}, \lambda 1$ corresponds to $500 \mathrm{~nm}$, and $\lambda 2$ at $550 \mathrm{~nm}$.

The Angström parameter was obtained from AOD data measured at AERONET stations to compare land measurements with values simulated by the models. The Angström parameter was determined, according to Equation (2):

$\alpha=-\ln \left(\frac{\tau \lambda 1}{\tau \lambda 2}\right) / \ln \left(\frac{\tau \lambda 1}{\lambda 2}\right)$

where $\tau_{\lambda}$ is the AOD at two wavelengths $\lambda_{1}$ and $\lambda_{2}$. The Angström parameter provides important information about the particle size. For relatively large particles, i.e., particle size comparable to wavelength, $\alpha$ is small ( $\alpha<1$, dust for example); whereas for small particles, the AOD varies more strongly with wavelength and typically $\alpha>1$. In addition, $\alpha$ has a dependence on moisture that causes the particles to increase in volume and subsequently decrease the Angström exponent.

In this analysis, version 2 (http://aeronet.gsfc.nasa.gov/), Level 2

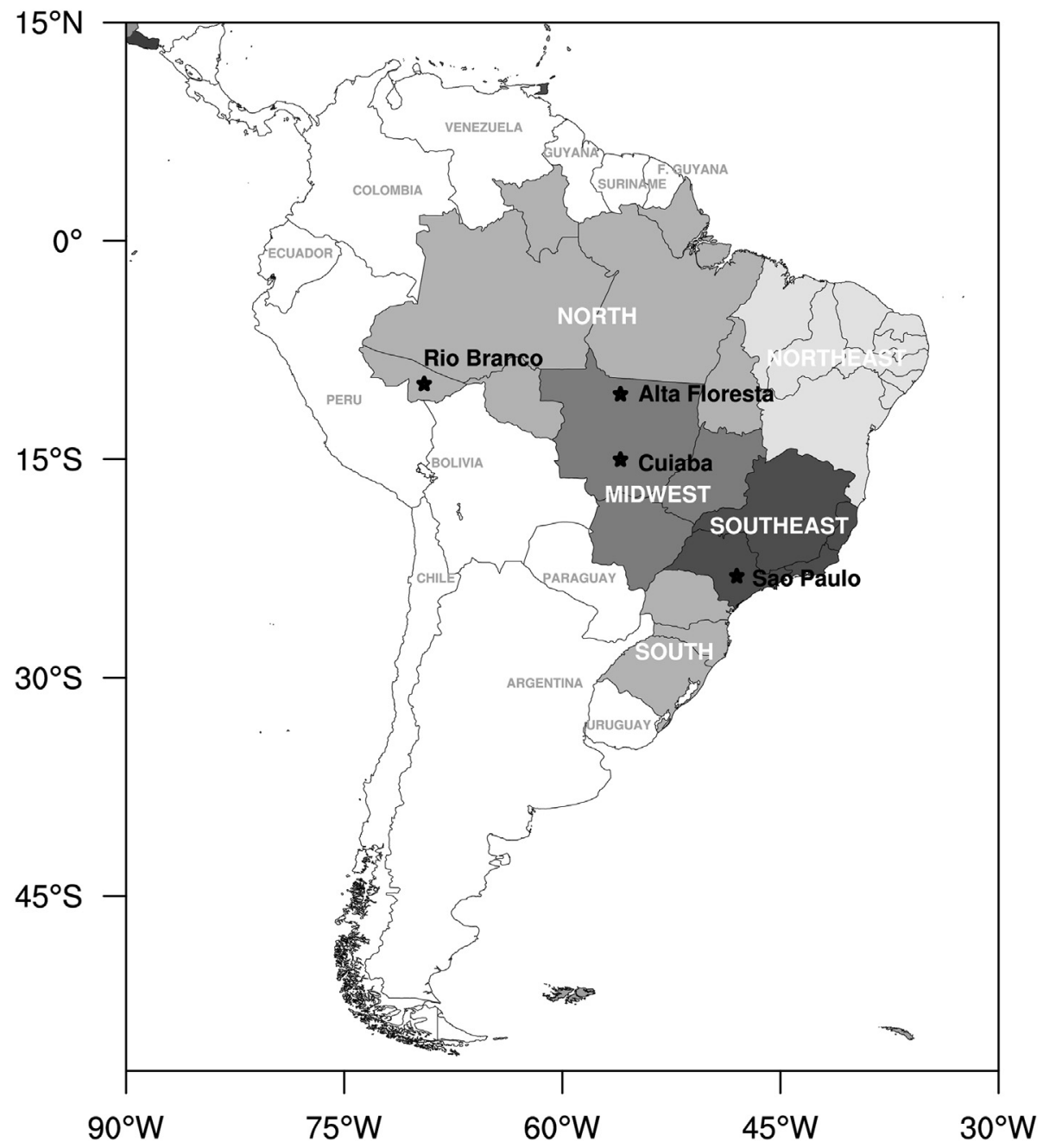

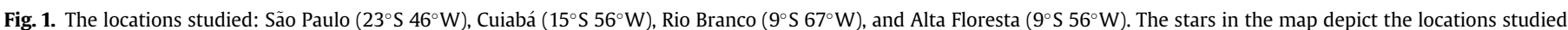


of AERONET data was used, first the AOD is calculated for $550 \mathrm{~nm}$ and $865 \mathrm{~nm}$ according to Equation (2), starting with AOD at $550 \mathrm{~nm}$, $\alpha$ is the Angström parameter between 440 and $675 \mathrm{~nm}$ and AOD at $675 \mathrm{~nm}, \alpha$ is the Angström parameter between 500 and $870 \mathrm{~nm}$, respectively, obtaining $\alpha$ at $550-865 \mathrm{~nm}$ to be comparable with the ECHAM-HAM model (Smirnov et al., 2000; Colarco et al., 2010).

\subsubsection{Satellite measurements}

Satellite observations of AOD are obtained from MODIS that has a scanning radiometer with 36 bands ranging between $0.4 \mu \mathrm{m}$ and $14.4 \mu \mathrm{m}$, on-board Terra and Aqua satellites of the National Aeronautics and Space Administration (NASA). The bands have spatial resolutions of $250 \mathrm{~m}$ (band $1=0.65 \mu \mathrm{m}$ and band $2=0.85 \mu \mathrm{m}$ ), $500 \mathrm{~m}$ (band $3=0.45 \mu \mathrm{m}$, band $4=0.55 \mu \mathrm{m}$, band $5=1.24 \mu \mathrm{m}$, band $6=1.64 \mu \mathrm{m}$ and band $7=2.11 \mu \mathrm{m}$ ) and $1000 \mathrm{~m}$ (Kaufman et al., 2002; Platnick et al., 2003). Daily products L3 global $1^{\circ} \mathrm{MG}$ were used. Monthly data of AOD with $1^{\circ} \times 1^{\circ}$ of spatial resolution from 2001 to 2006 (Terra), band $4=0.55 \mu \mathrm{m}$ belonging to the visible region. These data were interpolated for comparison with the models.

\subsection{Experiment design}

The ECHAM-HAM and CAM5-MAM3 models have been integrated for the period 2000-2006. The first year was used for spinup, and the other years were considered for the analysis of the results. The spatial and vertical resolutions for ECHAM-HAM are $1.9^{\circ} \times 1.9^{\circ}$ lat/lon and 31 vertical levels respectively. Sea surface temperature (SST) and sea ice concentration (SIC), anthropogenic emissions of aerosols and precursor gases were used from AeroCom II (Stevens et al., 2013; Stier et al., 2005; Lohmann and Hoose, 2009). The spatial and vertical resolutions for CAM5-MAM3 are $1.9^{\circ} \times 2.5^{\circ}$ lat/lon and 30 vertical levels. The SST, SIC, anthropogenic emissions of aerosol and precursor gases were used from AeroCom II. Both models use the same database for surface emission (AeroCom II for year 2000). However, CAM5-MAM3 also considers the emissions in vertical for all aerosols and their precursors used in the model.

The ECHAM-HAM uses emissions vertically for BC from aircraft and $\mathrm{BC}, \mathrm{OC}$ and $\mathrm{SO}_{2}$ from wildfire. The CAM5-MAM3, besides the mass emissions, also jointly uses emissions by particle number divided by the accumulation and Aitken modes (Neale et al., 2010). Table S1 to Table S13 are in the Supplementary material for a better understanding of the emission of aerosols and gases in the ECHAMHAM and CAM5-MAM3 model. Tables S1 and S2 show the surface emissions for BC, Tables S3 and S4 show emissions for OC and Table $\mathrm{S} 5$ shows emissions for $\mathrm{SO}_{2}$ of anthropogenic origin from the Aerocom II. Table $\mathrm{S} 6$ shows the anthropogenic surface emissions of the sulfate for accumulation and Aitken modes in the CAM5-MAM3 model. Table S7 shows the surface emission for Dimethyl Sulfide (DMS).

We highlight the main differences in the emissions in both the models, while ECHAM-HAM include DMS emissions in the ocean, CAM5-MAM3 considers only DMS emitted in the continent. ECHAM-HAM has emission of BC from aircraft in the vertical. Similar to ECHAM-HAM, CAM5-MAM3 considers $\mathrm{SO}_{2}$ emissions over the surface, in addition it also considers energy, industrial and vertical volcanic sources and the sulfate emissions are categorized into accumulation and Aitken modes in the energy, industry, forest fire, grassfire and volcanic sectors. Though not included in this work, CAM5-MAM3 also has separate emissions in two modes, Aitken and accumulation, over the surface for $\mathrm{BC}, \mathrm{OC}$ and $\mathrm{SO}_{4}^{2-}$ from forest and grass fire and $\mathrm{SO}_{4}^{2-}$ from volcanic and energy sector. In addition to the emissions shown in Tables S1, S2, S3 \& S4, Table S6 categorizes the emissions in both the modes.

\section{Results and discussions}

\subsection{Seasonal AOD variation over South America}

Figs. 2-6 show the seasonal mean AOD values for the period 2001-2006 measured by MODIS satellite (Terra) and simulated by CAM5-MAM3 and ECHAM-HAM over South America. These figures
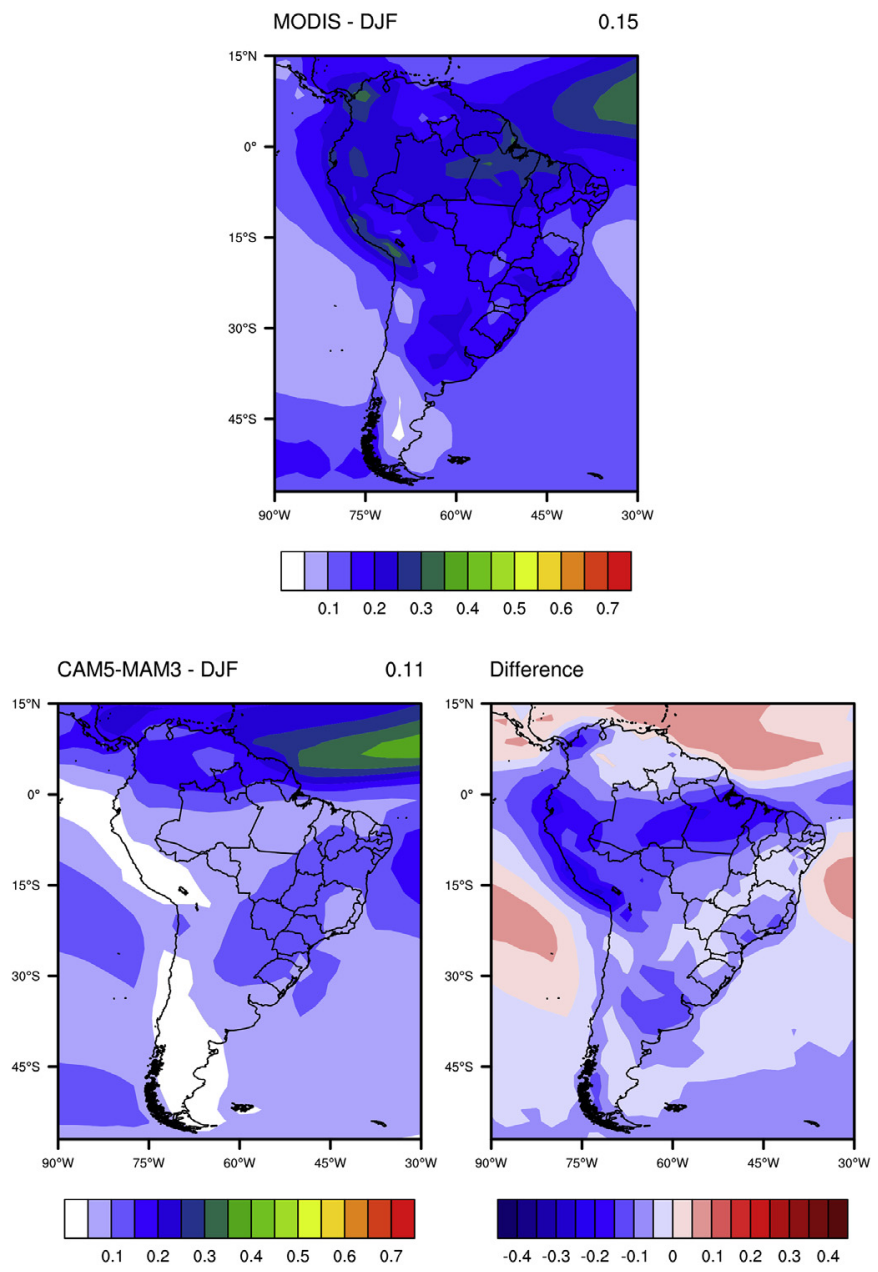

$\begin{array}{lllllll}0.1 & 0.2 & 0.3 & 0.4 & 0.5 & 0.6 & 0.7\end{array}$

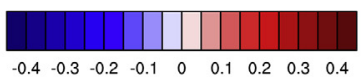

ECHAM-HAM - DJF 0.13
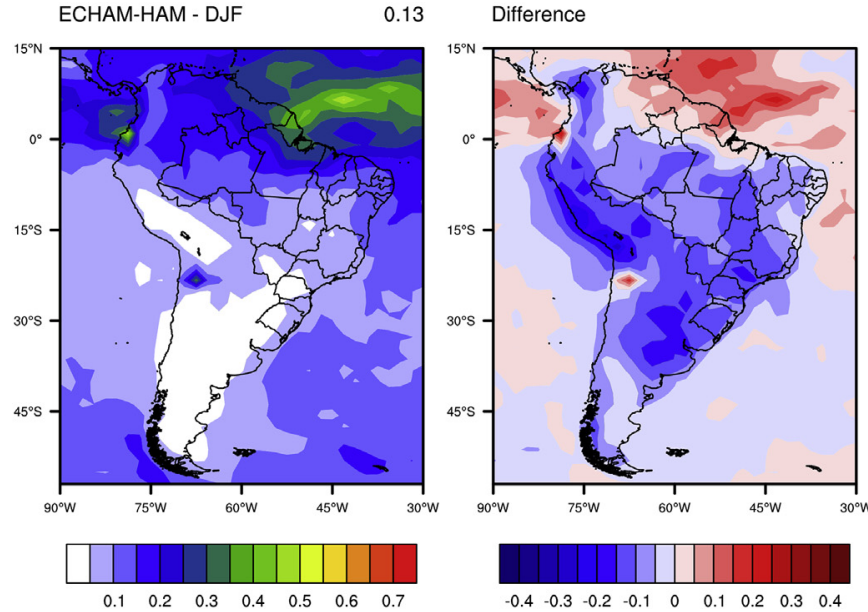

Fig. 2. Comparison of mean annual simulated AOD at $550 \mathrm{~nm}$ of CAM5-MAM3 and ECHAM-HAM models with the MODIS sensor for the period of DJF in 2001-2006 in Brazil. 

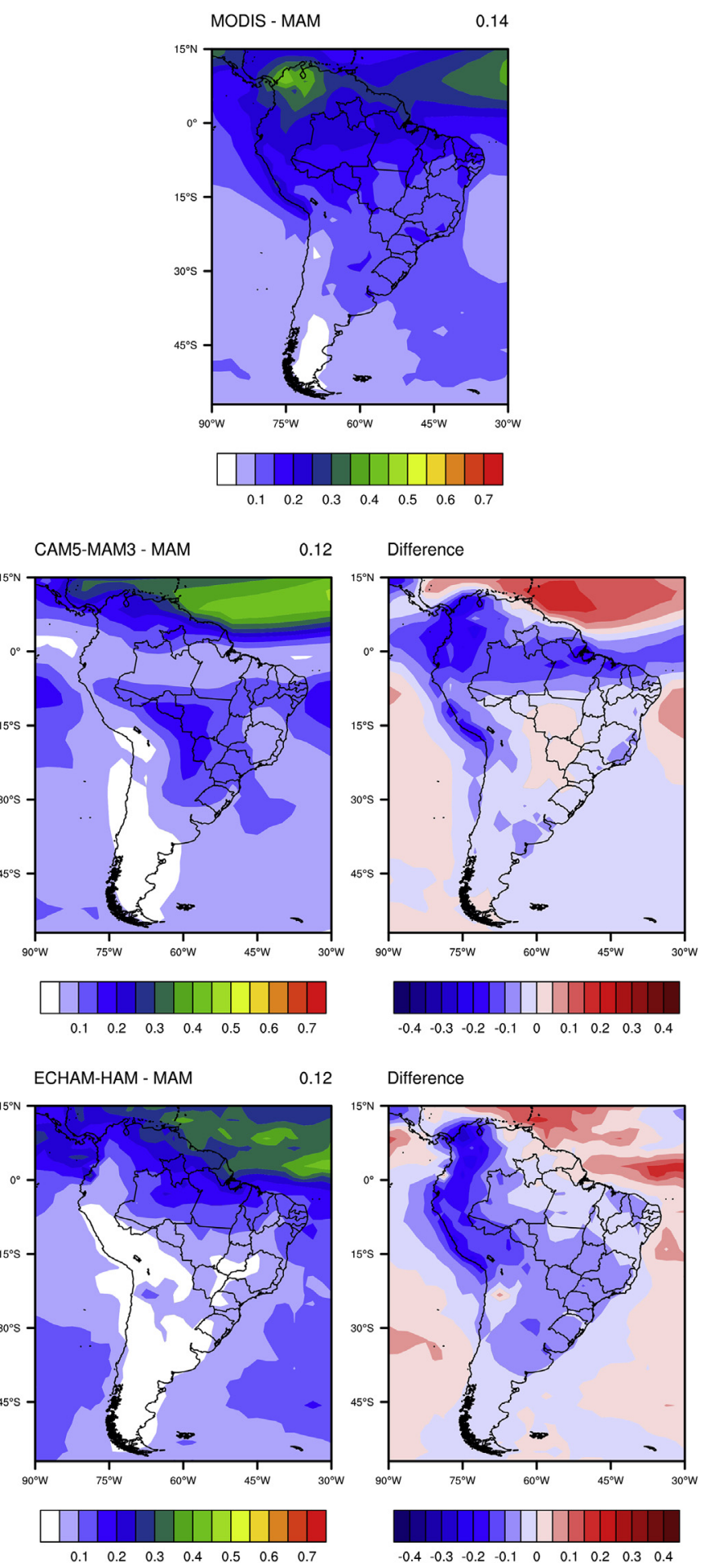

Fig. 3. Comparison of mean annual simulated AOD at $550 \mathrm{~nm}$ of CAM5-MAM3 and ECHAM-HAM models with the MODIS sensor for the period of MAM in 2001-2006 in Brazil.

show that both models underestimate AOD over South America during wet and dry season, whereas during dry season the CAM5MAM3 perform much better than ECHAM-HAM. It is interesting to observe in Figs. 2-6 that the maximum AOD values observed over southern Amazon, Rondônia and northern Mato Grosso (around $10^{\circ} \mathrm{S}$ and $58^{\circ} \mathrm{W}$ ), which is a the main Brazilian deforestation region, is well simulated by CAM5-MAM3 model, and shows that the
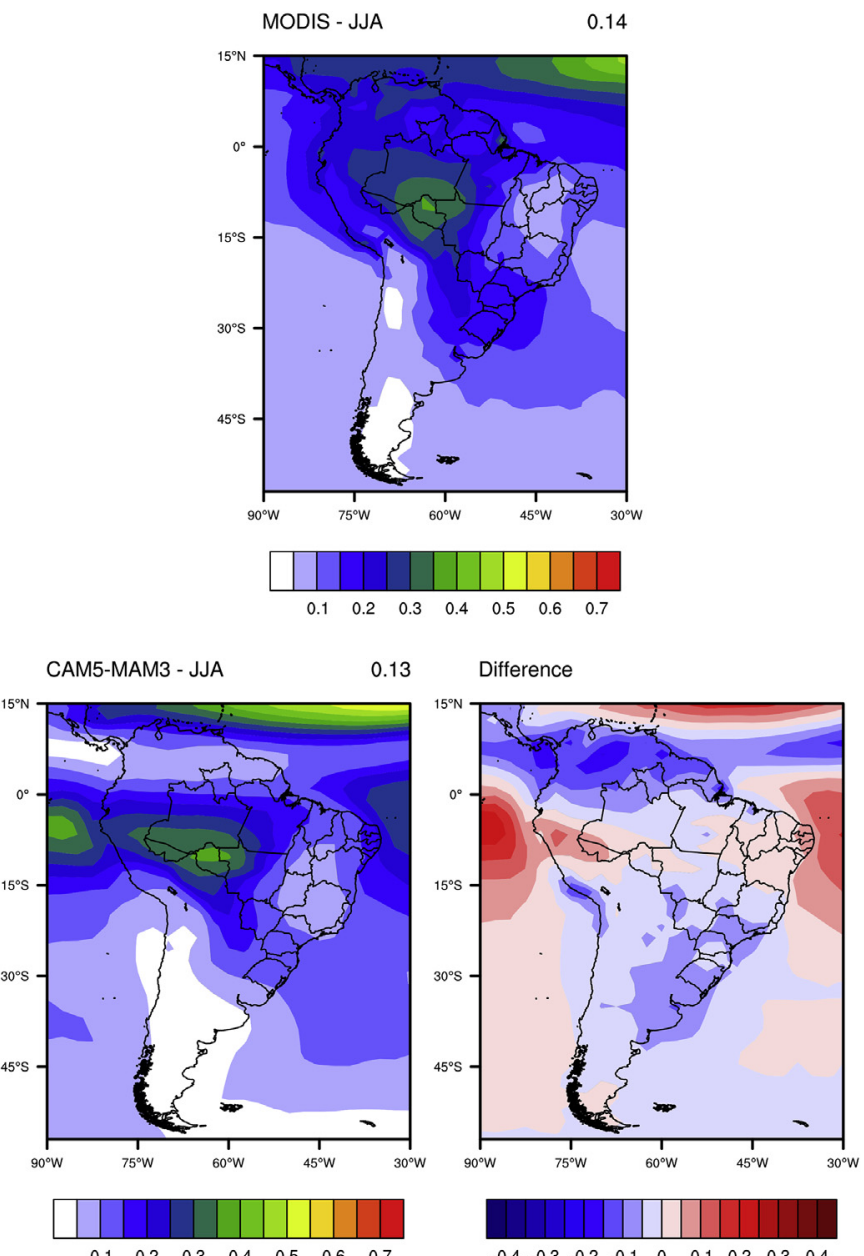

ECHAM-HAM - JJA

0.13

Difference
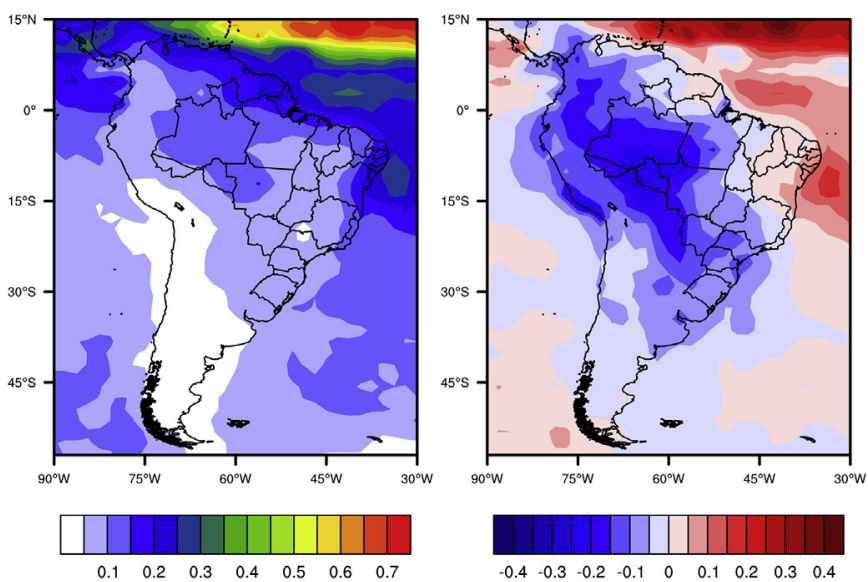

Fig. 4. Comparison of mean annual simulated AOD at $550 \mathrm{~nm}$ of CAM5-MAM3 and ECHAM-HAM models with the MODIS sensor for the period of JJA in 2001-2006 in Brazil.

highest concentrations of aerosols occur during ASO and SON (transition season) over Central of South America, around Central Brazil and Amazon Figs. 5 and 6. In ASO, values for concentrations are between 0.6 and 0.7 in all states of Rondônia and its boundary with the state of Mato Grosso owing to intense anthropogenic biomass burning (Artaxo et al., 2002), which is associated with agriculture practices (to clear areas for agriculture or maintain 
MODIS - ASO
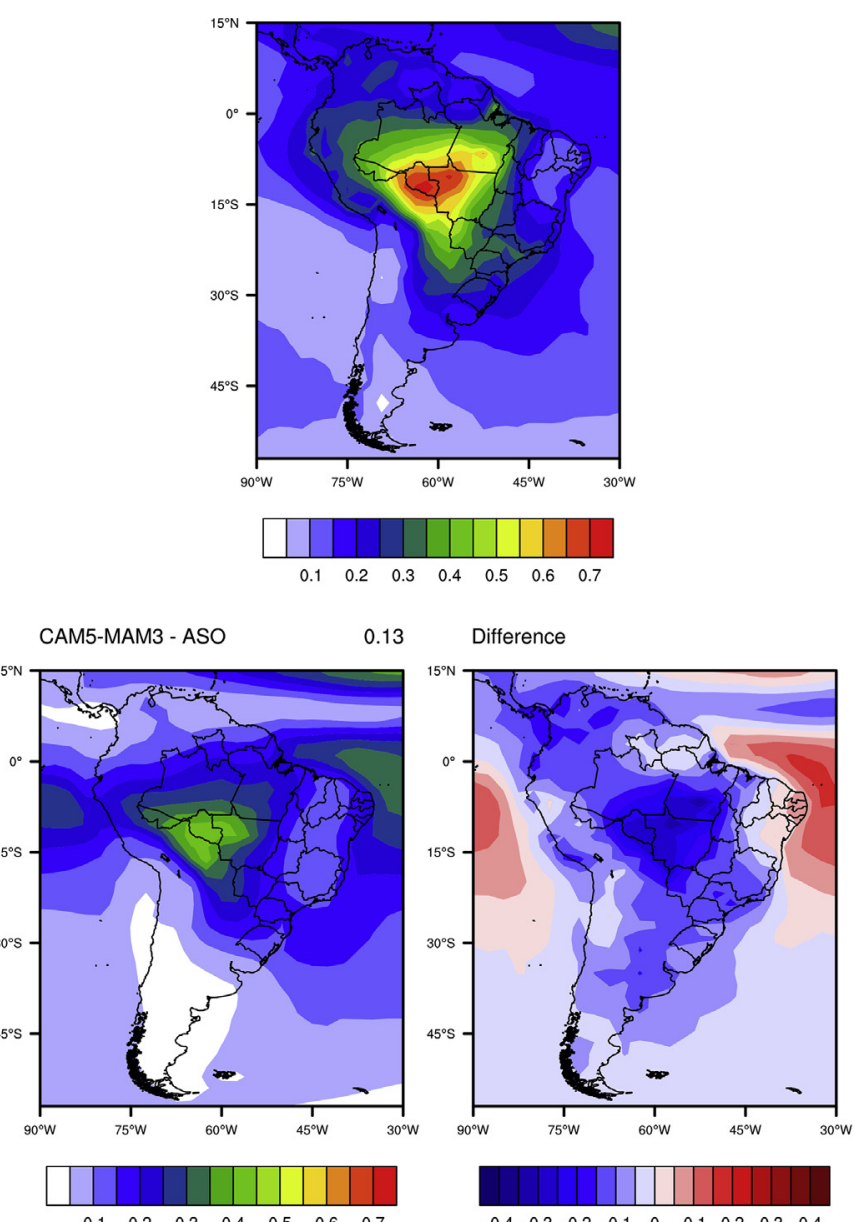

ECHAM-HAM - ASO

0.11
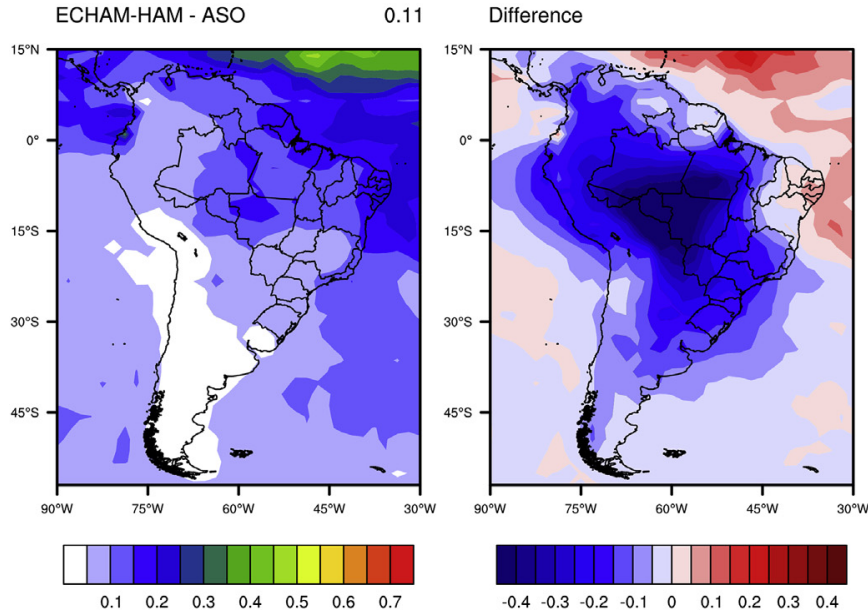

Fig. 5. Comparison of mean annual simulated AOD at $550 \mathrm{~nm}$ of CAM5-MAM3 and ECHAM-HAM models with the MODIS sensor for the period of ASO in 2001-2006 in Brazil.

pastures for livestock). For DJF, both the models underestimate AOD for practically every continental area of South America, with a small overestimation by ECHAM-HAM in the extreme north of South America. CAM5-MAM3 as well as the ECHAM-HAM simulations continue to underestimate the values, except in the states of Mato Grosso, Mato Grosso do Sul and South of Goiás and Rondônia where CAM5-MAM3 overestimates. However in JJA, the two models
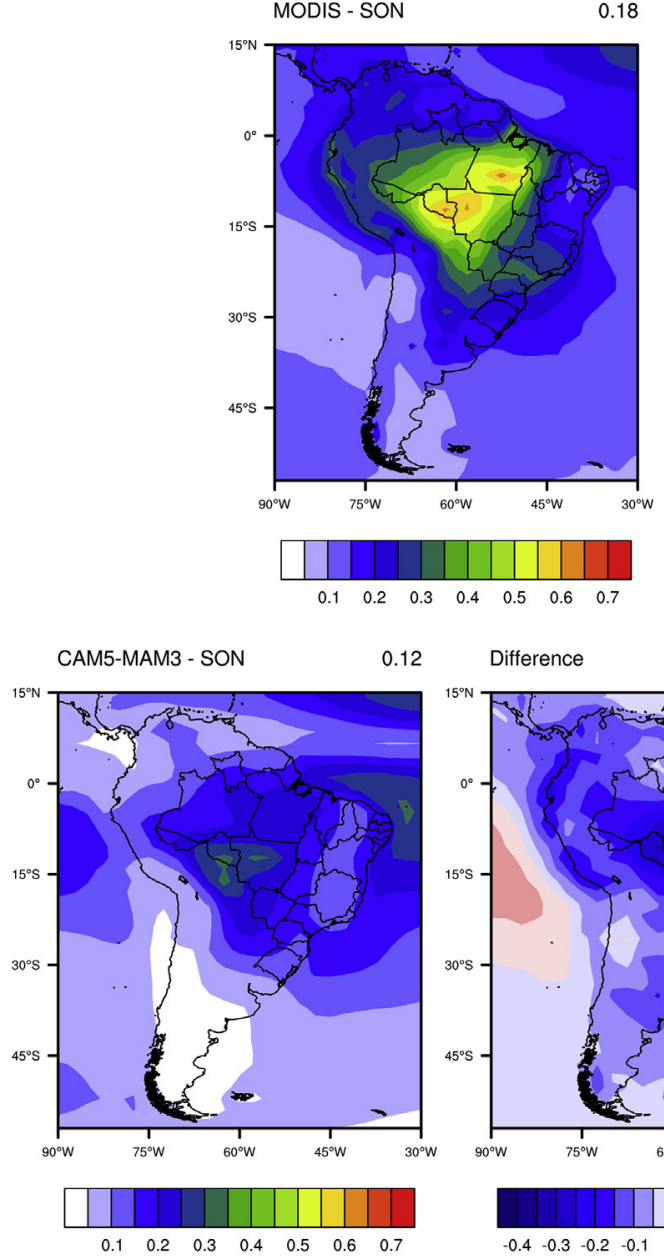

ECHAM-HAM - SON

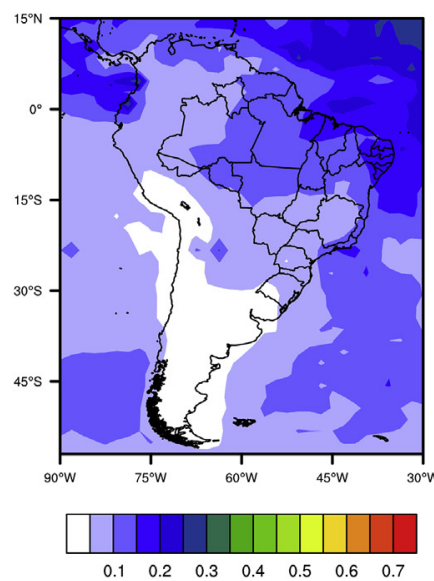

Difference

0.18

$\begin{array}{lllllllll}-0.4 & -0.3 & -0.2 & -0.1 & 0 & 0.1 & 0.2 & 0.3 & 0.4\end{array}$

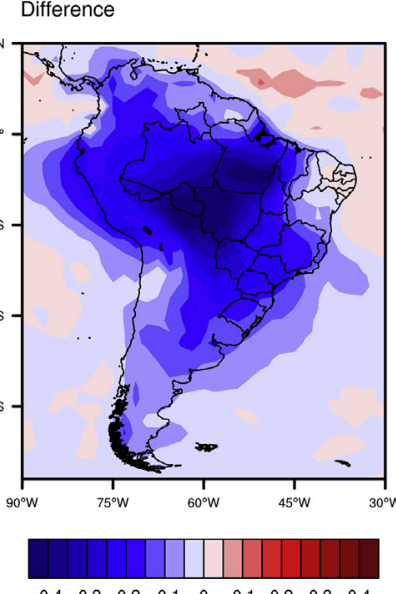

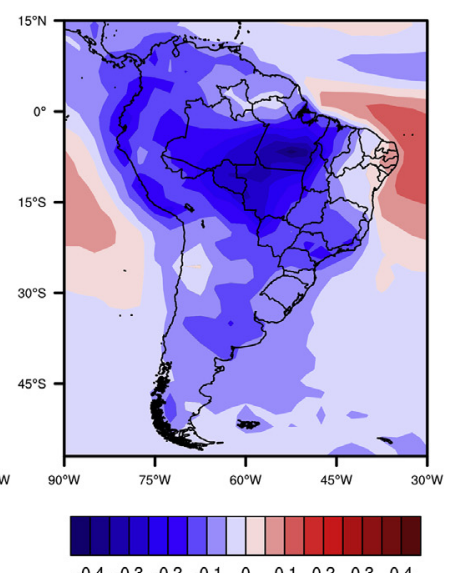

Fig. 6. Comparison of mean annual simulated AOD at $550 \mathrm{~nm}$ of CAM5-MAM3 and ECHAM-HAM models with the MODIS sensor for the period of SON in 2001-2006 in Brazil.

continue to underestimate AOD, but there is an overestimation over the coastal region of the Atlantic Ocean in the northeast region, probably due to the overestimation of the two models in the transportation of dust from the North African continent to South America. Differences in the results from both the models for DJF, MAM and JJA stations can be seen, but for the station with the highest concentration of aerosols in South America in SON and ASO, 
there is an intensification of negative bias over South America, an arc region of deforestation located on the edge of the Amazon Forest, where fires have an intra and inter-annual variability, directly associated with land use and land cover and with agricultural expansion. This region has significant importance in the global atmospheric circulation, characterized by deep convective motions, carrying heat and water vapor to the atmosphere of temperate regions. Biomass burning aerosols modify the radiation budget at the surface by absorbing and scattering incoming solar radiation. Over this region, both models are not able to represent properly the seasonality of aerosols emissions from biomass burning (see Fig. 8), such as black carbon and primary organic aerosol (POA) that are emitted in higher concentrations during the dry season, over the Amazon region. As a matter of fact, in both models the emissions are underestimated in the dry season, when there is an increase in forest fires, resulting in lower values of the simulated AOD against the measured values.

Fig. 7 depicts the annual correlation between observed and simulated AOD over South America. As shown in Fig. 7, the CAM5MAM3 model has a positive correlation for almost every continent in South America except for the region of northeastern Brazil and for some areas in the Atlantic and Pacific Ocean. The ECHAM-HAM model show lower correlations, present major errors over the North, Northeast and Southeast regions of Brazil. It is verified that there are not great variations in the performance of the two models for the result of the simulations of each year. The CAM5-MAM3 model simulated the AOD over Brazil better than the ECHAM-HAM. We can summarize that although both models underestimate the aerosol concentration during September to March (wet season) over South America, during dry season (JJA) the CAM-MA3
MODIS X CAM5-MAM3 2001
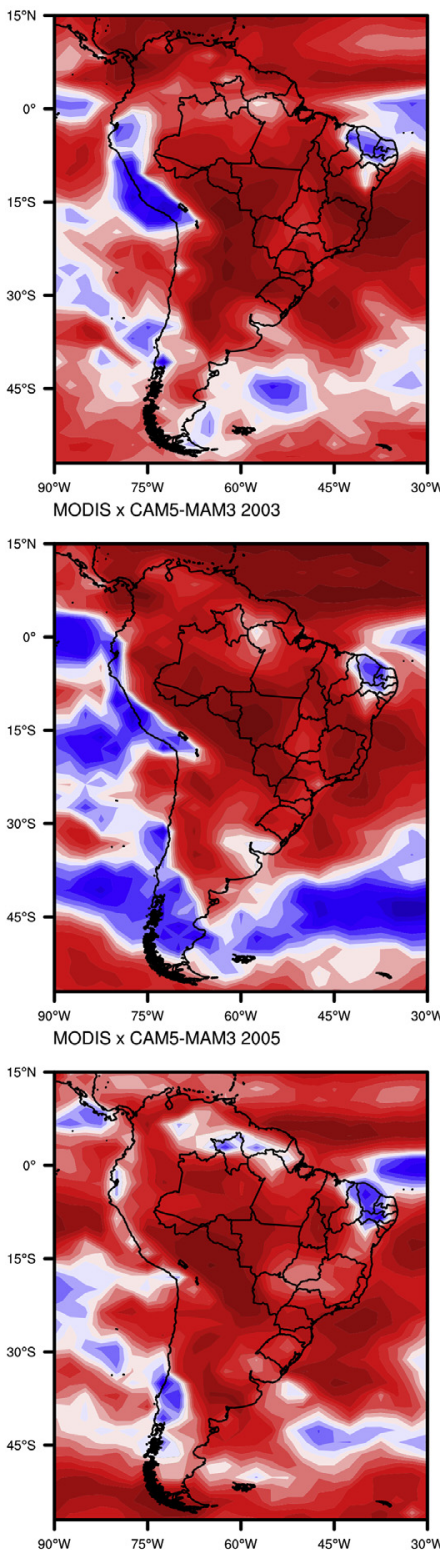

MODIS X ECHAM-HAM 2001

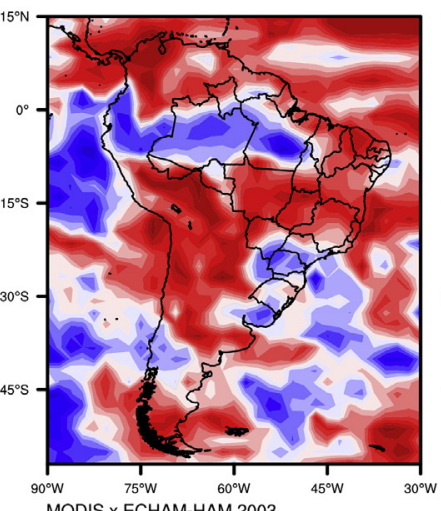

MODIS $\times$ ECHAM-HAM 2003

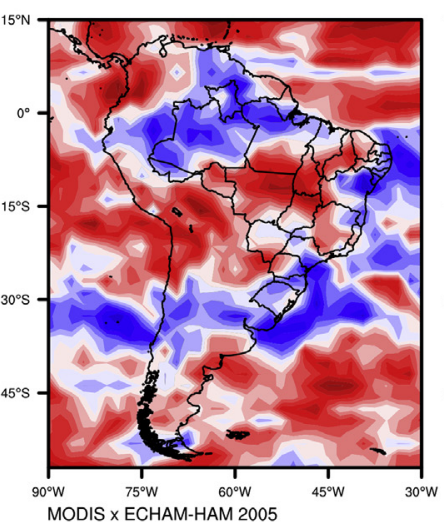

MODIS X CAM5-MAM 2002

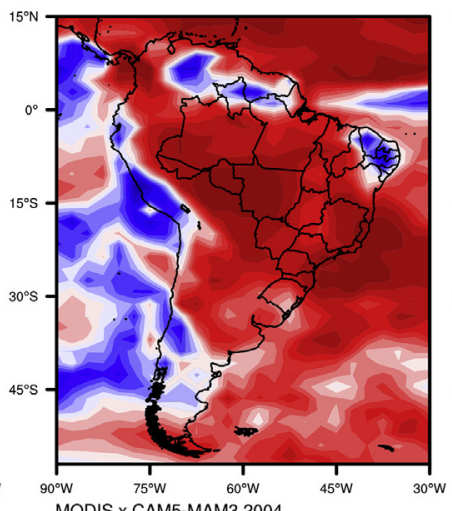

MODIS $\times$ CAM5-MAM3 2004

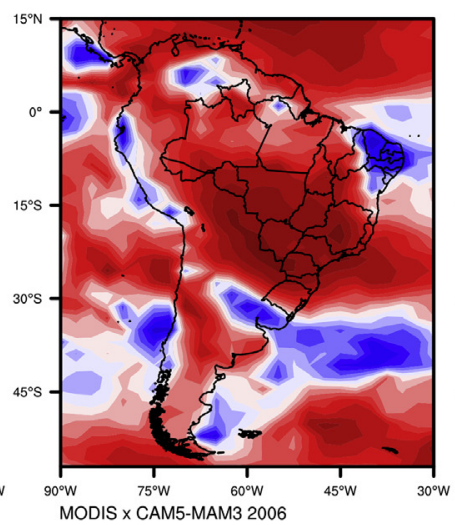

MODIS X ECHAM-HAM 2002

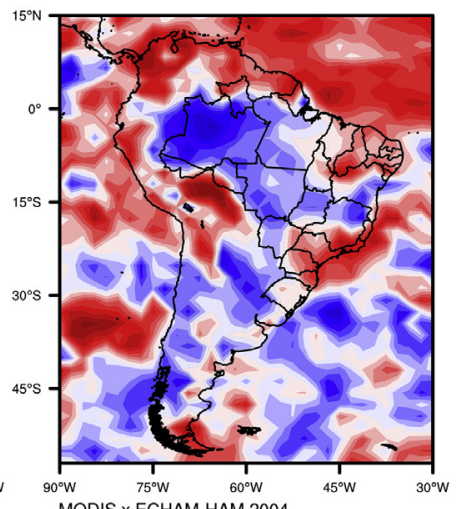

MODIS $x$ ECHAM-HAM 200
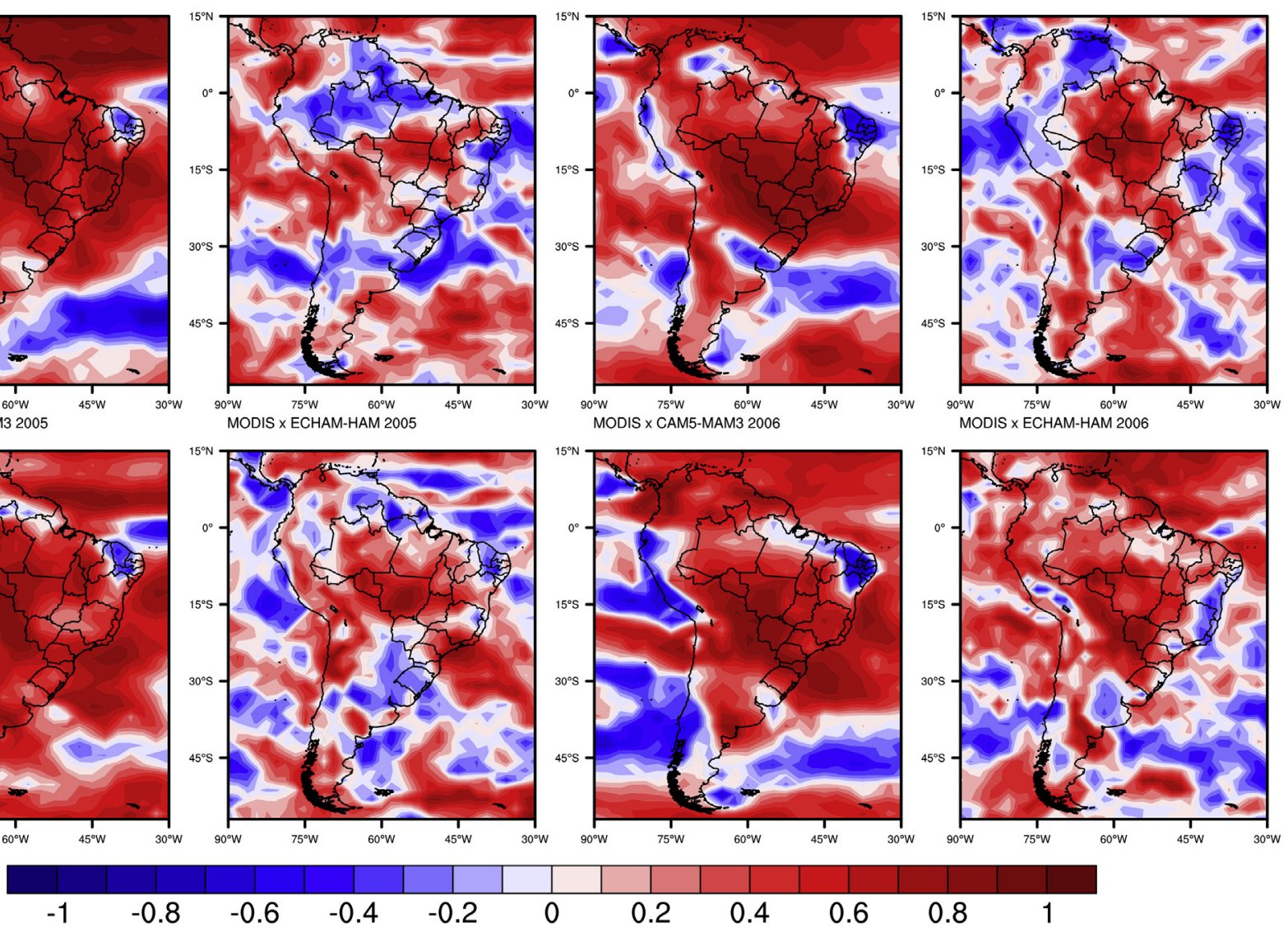

$-0.6-0.4$

$-0.2$

0

0.2

0.4

0.6

0.8

1

Fig. 7. MODIS sensor x CAM5-MAM3 and ECHAM-HAM AOD correlation in 2001-2006 in Brazil. 
performs much better than ECHAM-HAM, mainly around the Amazon and Central Brazil. Since the aerosol emissions used here are based on monthly climatological values, it is expected that the daily variation of local sources and the interaction between the individual fire episodes and specific transportation patterns cannot be reproduced accordingly.

Table 1 shows the coefficient of determination (R2) for monthly AOD observed data from MODIS sensor and AERONET station and simulations with ECHAM-HAM and CAM5-MAM3 model.

\subsection{Monthly AOD variation over some AERONET stations}

The monthly AOD long term means for the period 2001-2006, as measured by MODIS and AERONET stations at the four sites and the simulation results from ECHAM-HAM and CAM5-MAM3 models are shown in Fig. 8. The results over four sites show that the AOD simulated from both models are closer to observations during the period from January to June and November and December (when forest and agriculture fires decrease), while not representing well the period with the highest number of fire occurrences, i.e., from July to October. The CAM5-MAM3 model shows a fairly good representation of AOD for this period, even though the results are underestimated. These results are consistent with values of coefficient of determination, $\mathrm{R}^{2}$, for monthly AOD values, shown in Table 1.

São Paulo being the seventh most populated city in the world has higher AOD levels during DJF (Fig. 8a) compared to the other 3 cities considered in this study. Vehicular sources amount to $39 \%$ of particulate matter of the total 4500 tons emitted annually (CETESB, 2014). In the other 3 cities, AOD increases 2-4 times during the biomass-burning season from August to October, as shown in
Table 1

Coefficient of determination $\left(\mathrm{R}^{2}\right)$ for monthly AOD observed data from MODIS sensor and AERONET station and simulations with ECHAM-HAM and CAM5-MAM3 model.

\begin{tabular}{llllll}
\hline & \multicolumn{2}{l}{ AOD } & & \\
\cline { 2 - 3 } \cline { 5 - 6 } & \multicolumn{2}{l}{ CAM5-MAM3 } & & \multicolumn{2}{l}{ ECHAM-HAM } \\
\cline { 2 - 3 } \cline { 5 - 6 } & MODIS & AERONET & & MODIS & AERONET \\
\hline São Paulo & 0.80 & 0.72 & & 0.39 & 0.41 \\
Cuiabá & 0.80 & 0.75 & & 0.32 & 0.65 \\
Rio Branco & 0.86 & 0.72 & & 0.77 & 0.15 \\
Alta Floresta & 0.82 & 0.74 & 0.69 & 0.47 \\
\hline
\end{tabular}

Fig. $8 b-d$. The predominant air circulation transports the smoke resulting from biomass burning in the Amazonian states of Pará, Rondônia, Amazonas, and Acre to the west of South America, namely Peru, Bolivia and Paraguay (Artaxo et al., 2002; Andreae and Merlet, 2001; Hoffer et al., 2006; Freitas, 2014) contributing to an increase in air pollution levels in these neighboring countries.

Along with Mato Grosso, these four Amazonian states also report the highest number of fire occurrences in South America. In the region of Cuiabá (Mato Grosso state), forest fires and biomass burning in urban areas are common (mainly for clearing land and burning garbage) and are intensified during the dry season. The cleaner air prevailing in the rainy season in Rio Branco and Alta Floresta changes significantly in the dry season with large emission and higher concentration of aerosols resulting from biomass burning (Andreae et al., 2002). In the dry season, the particle number increases from a typical 200-300 particles $\mathrm{cm}^{-3}$ to 10,000-20,0000 particles $\mathrm{cm}^{-3}$ (Artaxo et al., 2002). In the wet season, the concentration of particulate matter, $\mathrm{PM}_{10}(\sim 10 \mu \mathrm{m}$ or
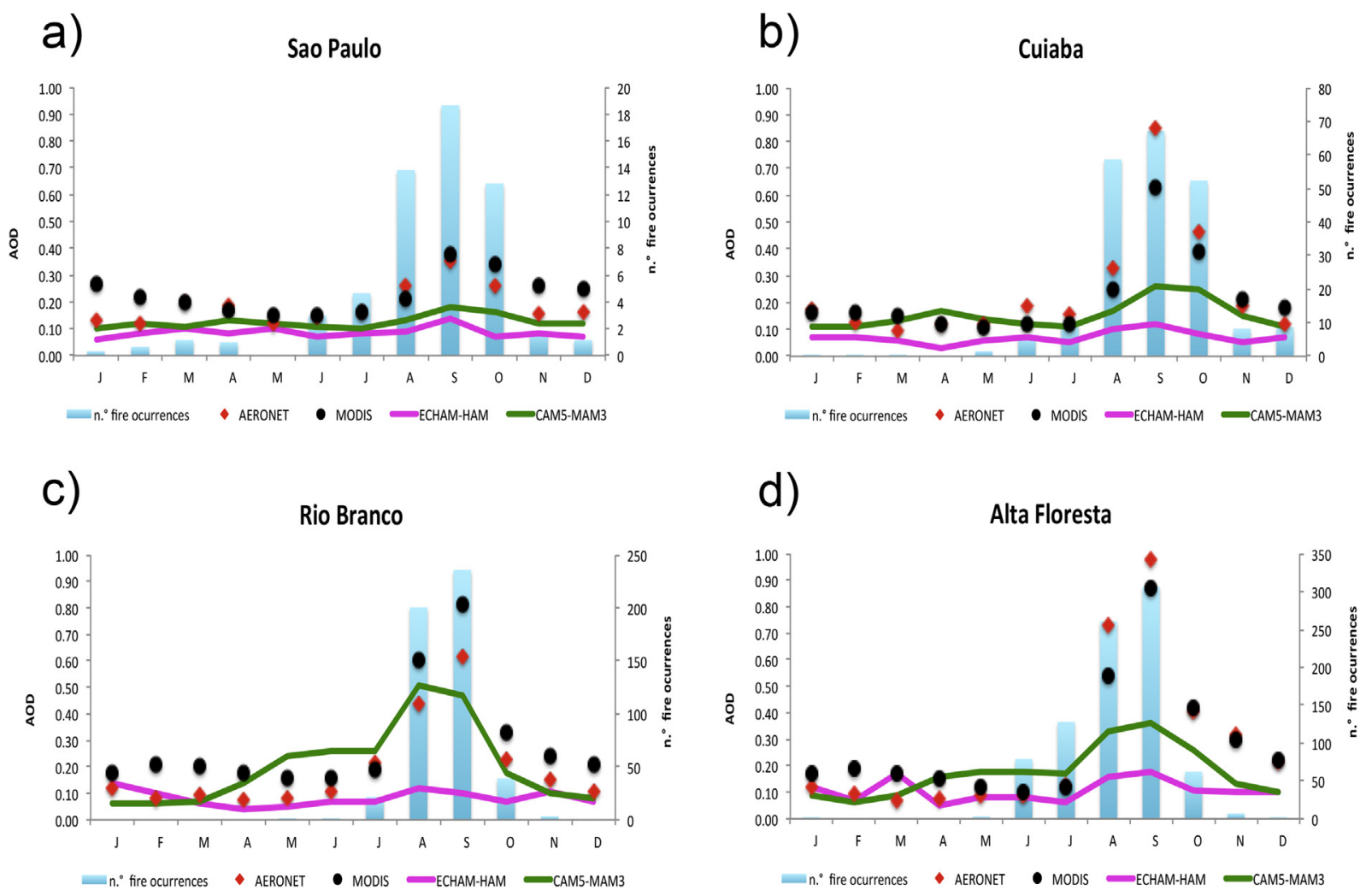

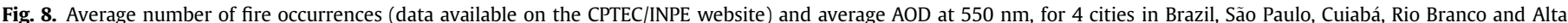

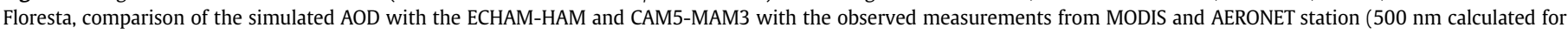
$550 \mathrm{~nm}$ ), for the period from 2001 to 2006. 
less), is typically between $10 \mu \mathrm{g} \mathrm{m}^{-3}$ and $12 \mu \mathrm{g} \mathrm{m}^{-3}$ while it reaches extremely high values, around $600 \mu \mathrm{g} \mathrm{m}^{-3}$, in the dry season. These high aerosol concentrations are hazardous to human health, and also impacts clouds and the radiation balance (Kaufman et al., 1998).

Long-term measurements over a region provide a temporal profile of the prevailing atmospheric properties. NASA's AERONET program maintains an operational network of 10 solar photometers in Brazil. The strong change in surface radiation fluxes has important effects on several aspects of the Amazonian ecosystem. A net surface cooling of $2{ }^{\circ} \mathrm{C}-3{ }^{\circ} \mathrm{C}$ as well as heating at $2-3 \mathrm{~km}$ altitude can be modeled by means of aerosol layer. This effect stabilizes the vertical temperature profile and reduces the convective transport of water vapor to higher levels of the troposphere. The radiation field is also strongly affected with a decrease in direct solar radiation at the surface, and an increase in diffuse solar radiation reaching the forest (Artaxo et al., 2009).

As shown by Oliveira et al. (2007), a slight increase in the atmospheric aerosol increases the fraction of scattered and direct radiation. Therefore, the vegetation improves the efficiency of the use of solar radiation and also increases the net primary productivity (NPP), defined as the net flow of atmospheric carbon to vegetation per unit time. Clean conditions, characterized by AOD $\sim 0.1$ at $500 \mathrm{~nm}$ to AOD $\sim 1.2$, indicate an increase in NPP from $30 \%$ to $50 \%$ in the dry season and $24 \%$ in the wet season in Rondônia. Once AOD at $500 \mathrm{~nm}$ exceeds 1.2 , a reduction in the total flow starts to decrease carbon assimilation, and with an AOD about $3-4$, the vegetation no longer assimilates carbon due to the high reduction of solar radiation flux (Oliveira et al., 2007; Artaxo et al., 2009). The highest values of AOD in September for Rio Branco (0.81) and Alta Floresta (0.87) found in this study complements the number of fire occurrences, 236 and 237 respectively, for these sites during the same period. Fig. 9 shows the mean Angström exponent to be greater than 1 for all the four sites, which is typical for the small particles originating from biomass burning and fossil fuels (Smirnov et al., 2000; Colarco et al., 2010). For the region of São Paulo, aerosols from vehicular emissions, especially from diesel vehicles, release gases that lead to the formation of small particles (secondary aerosols). According to Silva et al. (2012) and Fajersztajn et al. (2013), among all of the air pollutants, aerosols (primary and secondary) are the most harmful to health. In San Francisco, California, though just over $10 \%$ of cars use diesel as fuel, over $60 \%$ of the secondary organic aerosols (SOA) harmful to human health are generated. The São Paulo Metropolitan city has a fleet of 7 million vehicles of which approximately $6 \%$ are powered by diesel. In addition, it is route to a traffic of heavy, diesel-fueled vehicles moving between the greatly industrialized countryside of São Paulo state and the coast, presenting similar characteristics as California concerning the production of SOA from this type of fuel (CETESB, 2014; Gentner et al., 2012). From the measurements taken in 2012 in the city of São Paulo (Almeida et al., 2013), it was found that the most abundant observed species were the organic and $\mathrm{BC}$, representing $86 \%$ of the total mass of aerosols ( $49.3 \%$ and $36.9 \%$ for organic and BC, respectively), implying the relevant impact of use of the diesel as vehicle fuel. Other species contributed to $5.6 \%, 4.3 \%$, $3.4 \%$, and $0.4 \%$, for $\mathrm{SO}_{4}^{2-}, \mathrm{NO}_{3}^{-}, \mathrm{NH}_{4}^{+}$, and $\mathrm{Cl}^{-}$, respectively, justifying

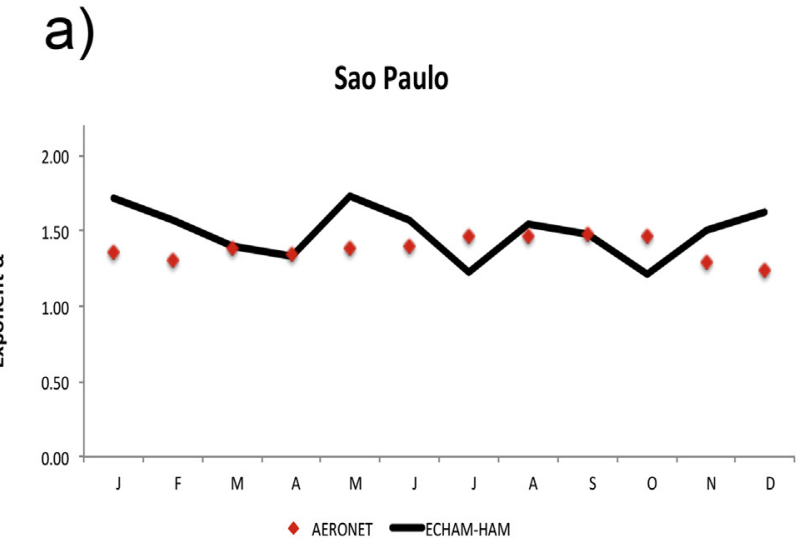

b)

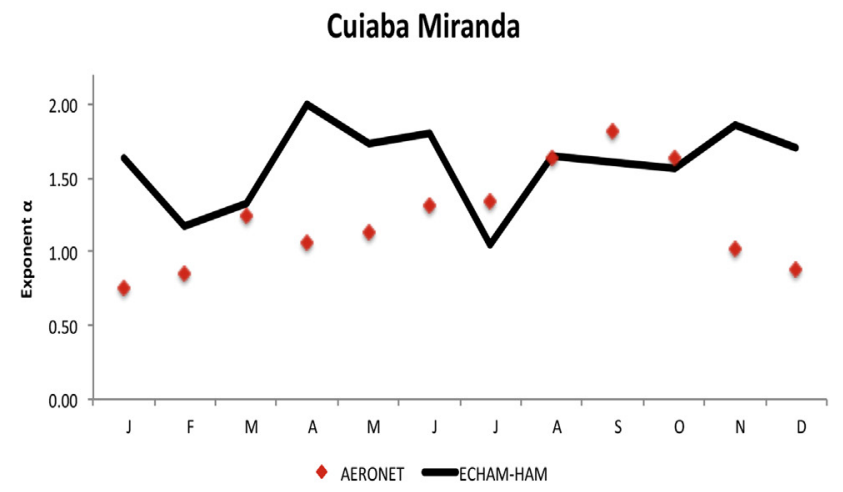

d)

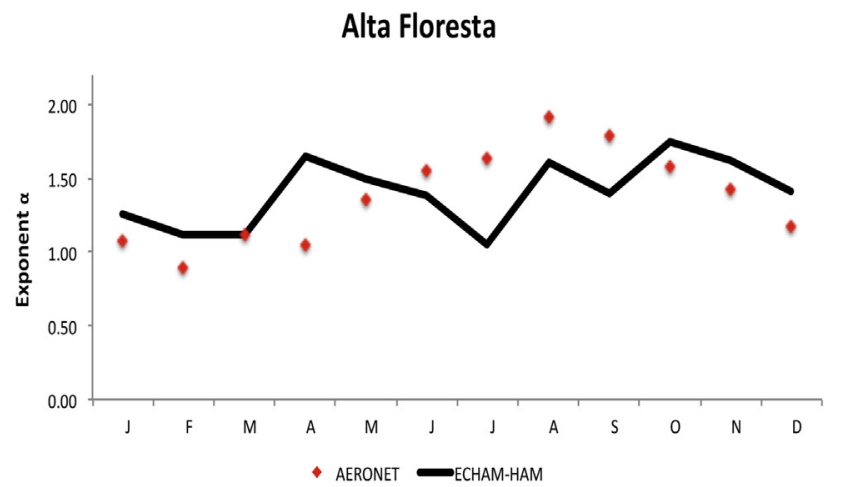

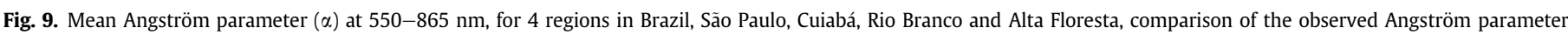
(calculated from the observed AOD) and measurements of AERONET station and simulations with the ECHAM-HAM model in the 2001-2006 period. 
the mean value of 1.4 for the Angström parameter from AERONET measurements and 1.5 simulated by ECHAM-HAM with fine mode particles.

According to previous studies in the area (Ynoue and Andrade, 2004), the contribution of organic products and BC to the total mass fraction is much higher than that observed for inorganic origins. In the Cuiabá region, the Angström exponent increases from June to October with the number of fire occurrences from biomass burning and urban fires. The highest values of the Angström exponent, AOD and number of fire occurrences observed during the months of August, September, and October for regions of Cuiabá, Rio Branco, and Alta Floresta indicate the strong dominance of fine mode aerosols.

\section{Conclusions}

This paper focuses on assessing the performance of two of the existing state-of-the-art climate models with online aerosol module in representing solely the direct effect of aerosols over Brazil. The authors do not intend to compare the models in totality. In fact, the results presented here suggest improvements for better representation of aerosols in the global models. Indirect effects of aerosols have a larger influence on the atmospheric processes however, given its wide domain and complexity, it is beyond the scope of the present paper.

The importance of studying both observed and simulated aerosol properties in Brazil is twofold. One, the primary sources of aerosol particles are direct emissions of vegetation, biomass burning and fossil fuels use. The secondary aerosol production in the atmosphere is originated from emissions of Volatile Organic Compounds (VOCs) from many sources, such as vegetation, biomass burning, and fossil fuels, which undergo photochemical processes. Other relevant factors for the concentration of aerosols over South America and the neighboring oceans are: the transport of Sahara desert dust and biomass burning from Africa to Northern South America and tropical North Atlantic; the transport of aerosols produced during biomass burning in Brazil to other countries in South America and to the southern Atlantic Ocean.

In this study, we explored the ability of ECHAM-HAM and CAM5-MAM3 models, focusing on comparing optical parameters (both in spatial structure and amplitude) simulated by the models AOD and Angström parameter - with directly satellite data and observed measurements from four ground stations in Brazil.

The Angström parameter is properly reproduced in most seasons by ECHAM-HAM, indicating that the particle size distribution is correctly simulated, with the exception of Cuiabá, which shows a difference in the measured and modeled Angström parameter of $46 \%$, where ECHAM-HAM overestimates the parameter for almost the entire year, while for other regions the difference was around $17 \%$.

The results show an underestimation of AOD values and an absence of seasonality during the dry season. This underestimation is also confirmed by spatial AOD maps in comparison with satellite and terrestrial measurements products (Liu et al., 2012; Zhang et al., 2012).

Perhaps one possible explanation for the better results of AOD for the CAM5-MAM3 in relation to ECHAM-HAM is that the NCAR model also considers the vertical profile of emissions and particle numbers separated by accumulation and Aitken modes, in addition to the surface emission of aerosols and their precursors. This is probably a closer estimate of reality, than considering just the surface emissions and vertical distribution emission only of black carbon from aircraft and $\mathrm{BC}, \mathrm{OC}$, and $\mathrm{SO}_{2}$ from wildfire, as it is considered in ECHAM-HAM. For all other emissions in ECHAMHAM, such as the energy sector, domestic or industry, only surface emissions are considered.

It is important to note that a comparison of the aerosol measurements and model results in Brazil is particularly difficult because aerosol measurements are scarce. More detailed measurements over the region are needed in order to adjust the models to the regional characteristics of Brazil.

From the results based solely on the direct effect of aerosols, the present study is not conclusive on the performance of both the model in representing the processes related to the aerosol component. A comprehensive study addressing the simulated indirect effects with varying the existing schemes for radiation, convection and cloud microphysics and its comparison with the ongoing implementation of the aerosol component in the Brazilian Earth System Model (BESM, Nobre et al., 2013) is a focus of the next article and would provide for more detailed analysis on the representation of aerosol component over Brazil in a wide range of existing global aerosol models.

\section{Acknowledgements}

The authors express their gratitude for Fundação de Amparo à Pesquisa do Estado de São Paulo - FAPESP (Sao Paulo State Research Foundation) for providing the post-doc fellowships for Débora Souza Alvim and Jayant Pendharkar under contract number 2014/06411-5 and 2014/03149-8, respectively, relative to the project "Brazilian Earth System Model - BESM/FAPESP - 2009/505286 ". This work was partially funded for the development of BESM by Financiadora de Estudos e Projetos - FINEP under grant $\mathrm{n}^{\circ}$ 01.12.0183.00 and IBAS/MOST under grant $n^{\circ}$ 490237/2011-8.

\section{Appendix A. Supplementary data}

Supplementary data related to this article can be found at http:// dx.doi.org/10.1016/j.apr.2017.01.008.

\section{References}

Almeida, G.P., Brito, J., Morales, C.A., Andrade, M.F., Artaxo, P., 2013. Measured and modeled Cloud Condensation Nuclei (CCN) concentration in São Paulo, Brazil: the importance of aerosol size-resolved chemical composition on CCN concentration prediction. Atmos. Chem. Phys. Discuss. 13, 32353-32389. http:// dx.doi.org/10.5194/acpd-13-32353-2013.

Andreae, M.O., Merlet, P., 2001. Emission of trace gases and aerosols from biomass burning. Glob. Biogeochem. Cycles 15, 955-966. http://dx.doi.org/10.1029/ 2000 GB001382.

Andreae, M.O., Almeida, S.S., Artaxo, P., Brandão, C., Carswell, F.E., Ciccioli, P., Culf, A., Esteves, J.L., Gash, J., Grace, J., Kabat, P., Lelieveld, J., Malhi, Y., Manzi, A.O., Meixner, F.X., Nobre, A., Nobre, C., Ruivo, M.A.L., Silva-Dias, M.A.F., Stefani, P., Valentini, R., Jouanne, J. Von, Waterloo, M., 2002. Biogeochemical cycling of carbon, water, energy, trace gases and aerosols in Amazonia: the LBA-EUSTACH experiments. J. Geophys. Res. 107 (D20), 8066. http://dx.doi.org/10.1029/ 2001JD000524.

Artaxo, P., Martins, J.V., Yamasoe, M.A., Procópio, A.S., Pauliquevis, T.M. Andreae, M.O., Guyon, P., Gatti, L.V., Leal, A.M.C., 2002. Physical and chemical properties of aerosols in the wet and dry season in Rondônia, Amazonia. J. Geophys. Res. 107 (D20), 8081-8095. http://dx.doi.org/10.1029/ 2001JD000666.

Artaxo, P., Rizzo, L.V., Paixão, M., Lucca, S., Oliveira, P.H., Lara, L.L., Wiedemann, K.T., Andreae, M.O., Holben, B., Schafer, J., Correia, A., Pauliquevis, T.M., 2009. Aerosol Particles in Amazonia: Their Composition, Role in the Radiation Balance, Cloud Formation, and Nutrient Cycles. Amazonia and Global Change Geophysical Monograph Series 186 Copyright 2009 by the American Geophysical Union, 10.1029/2008GM000778. http://dx.doi.org/10.1029/GM186.

Bond, T.C., Bergstrom, R.W., 2006. Light absorption by carbonaceous particles: an investigative review. Aero. Sci. Tech. 40, 27-67.

CETESB - Environmental Sanitation Technology Company, 2014. Air Quality Report in São Paulo - 2013, 0103-4103.

Climate Change Science Program, 2009. Atmospheric aerosol properties and climate impacts. Synthesis Assess. Prod. 2.3, 128. Available from: http://downloads. climatescience.gov/sap/sap2-3/sap2-3-final-report-all.pdf.

Colarco, P., da Silva, A., Chin, M., Diehl, T., 2010. Online simulations of global aerosol distributions in the NASA GEOS-4 model and comparisons to satellite and ground-based aerosol optical depth. J. Geophys. Res. 115, D14207. http:// 
dx.doi.org/10.1029/2009JD012820.

Fajersztajn, L., Veras, M., Barrozo, L.V., Saldiva, P.H.N., 2013. Air pollution: a potentially modifiable risk factor for lung cancer. Nature Reviews Cancer. Nat. Publ. Group 13 (9), 674-678. http://dx.doi.org/10.1038/nrc3572 (PMID: 23924644).

Freitas, S.R., Longo, K.M., Rodrigues, L.F., 2009. Numerical modeling of the atmosphere chemistry composition and of its impacts on weather, climate and air quality. Rev. Bras. Meteorol. 24 (2), 188-207. http://dx.doi.org/10.1590/S010277862009000200008

Freitas, S.R., 2014. Amazon Deforestation Increases Pollution in South American Countries. News Agency Foundation of São Paulo Research (FAPESP), Elton Alisson, of Rio Branco (AC), 2014. Available from: http://agencia.fapesp.br/ 19501.

Gentner, D.R., Isaacman, G., Worton, D.R., Chan, A.W.H., Dallmann, T.R., Davis, L., Liu, S., Day, D.A., Russell, L.M., Wilson, K.R., Weber, R., Guha, A., Harley, R.A., Goldstein, A.H., 2012. Elucidating secondary organic aerosol from diesel and gasoline vehicles through detailed characterization of organic carbon emissions. Proc. Natl. Acad. U. S. A. 109, 18318-18323. http://dx.doi.org/10.1073/ pnas.1212272109.

Ghan, S.J., Schwartz, S.E., 2007. Aerosol properties and processes: a path from field and laboratory measurements to global climate models. Bull. Amer. Meteor. Soc. 88, 1059-1083. http://dx.doi.org/10.1175/BAMS-88-7-1059.

Ghan, S.J., Zaveri, R.A., 2007. Parameterization of optical properties for hydrated internally mixed aerosol. JGR: atmospheres 112, D10. http://dx.doi.org/10.1029/ $2006 j d 007927$.

Giorgetta, M.A., Roeckner, E., Mauritsen, T., Bader, J., Crueger, T., Esch, M., Rast, S., Kornblueh, L., Schmidt, H., Kinne, S., Hohenegger, C., Möbis, B., Krismer, T., Wieners, K.H., Stevens, B., 2013. The atmospheric general circulation model ECHAM6-Model description. Rep. Earth Syst. Sci. 135.

Hansen, J., Sato, M., Kharecha, P., Russell, G., Lea, D.W., Siddall, M., 2007. Climate change and trace gases. Phil. Trans. Roy. Soc. A 365, 1925-1954. http:// dx.doi.org/10.1098/rsta.2007.2052.

Hess, M., Koepke, P., Schult, I., 1998. Optical properties of aerosols and clouds: the software package OPAC. Bull. Am. Met. Soc. 79 (5), 831-844.

Hobbs, P.V., Reid, J.S., Kotchenruther, R.A., Ferek, R.J., Weiss, R.M., 1997. Direct radiative forcing by smoke from biomass burning. Science 275, 1776-1778. http://dx.doi.org/10.1126/science.275.5307.1777.

Hoffer, A., Gelencser, A., Blazso, M., Guyon, P., Artaxo, P., Andreae, M.O., 2006. Diel and seasonal variations in the chemical composition of biomass burning aerosol. Atmos. Chem. Phys. 6, 3505-3515. http://dx.doi.org/10.5194/acp-63505-2006.

Holben, B.N., Tanre, D., Smirnov, A., Eck, T.F., Slutsker, I., Abuhassan, N., Newcomb, W.W., Schafer, J., Chatenet, B., Lavenue, F., Kaufman, Y.J., Vande Castle, J., Setzer, A., Markham, B., Clark, D., Frouin, R., Halthore, R., Karnieli, A., O'Neill, N.T., Pietras, C., Pinker, R.T., Voss, K., Zibordi, G., 2001. An emerging ground-based aerosol climatology: aerosol optical depth from AERONET. J. Geophys. Res. 106, 12067-12097. http://dx.doi.org/10.1029/2001JD900014.

Iacono, M., Delamere, J., Mlawer, E., Shephard, M., Clough, S., Collins, W., 2008. Radiative forcing by long-lived greenhouse gases: calculations with the air radiative transfer models. J. Geophys. Res. 113, D13103. http://dx.doi.org/ 10.1029/2008JD009944.

Jacobson, M.Z., 2001. Strong radiative heating due to the mixing state of black carbon in atmospheric aerosols. Nature 409, 695-697. http://dx.doi.org/ $10.1038 / 35055518$.

Kaufman, Y., Hobbs, P.V., Kirchhoff, V.W.J.H., Artaxo, P., Remer, L., Holben, B.N., King, M.D., Prins, E.M., Ward, D.E., Longo, K.M., Mattos, L.F., Nobre, C.A., Spinhirne, J., Thompson, A.M., Gleason, J.F., Christopher, S.A., 1998. Smoke cloud and radiation experiment in Brazil (SCAR-B). J. Geophys. Res. 103 (D24), 31783-31808. http://dx.doi.org/10.1029/98JD02281.

Kaufman, Y.J., Tanré, D., Boucher, O., 2002. A satellite view of aerosols in the climate system. Nature 419, 215-223. http://dx.doi.org/10.1038/nature01091.

Liu, X., Easter, R.C., Ghan, S.J., Zaveri, R., Rasch, P., Shi, X., Lamarque, J.F., Gettelman, A., Morrison, H., Vitt, F., Conley, A., Park, S., Neale, R., Hannay, C., Ekman, A.M.L., Hess, P., Mahowald, N., Collins, W., Iacono, M.J., Bretherton, C.S., Flanner, M.G., Mitchell, D., 2012. Toward a minimal representation of aerosols in climate models: description and evaluation in the Community Atmosphere Model CAM5. Geosci. Model Dev. 5, 709-739. http://dx.doi.org/10.5194/gmd-5-
709-2012.

Lohmann, U., Hoose, C., 2009. Sensitivity studies of different aerosol indirect effects in mixed-phase clouds. Atmos. Chem. Phys. 9, 8917-8934. http://dx.doi.org 10.5194/acp-9-8917-2009.

Neale, R.B., Chen, C.C., Gettelman, A., Lauritzen, P.H., Park, S., Williamson, D.L., Conley, A.J., Garcia, R., Kinnison, D., Lamarque, J.F., Marsh, D., Mills, M., Smith, A.K., Tilmes, S., Vitt, F., Cameron-Smith, P., Collins, W.D., Iacono, M.J. Easter, R.C., Ghan, S.J., Liu, X., Rasch, P.J., Taylor, M.A., 2010. Description of the NCAR Community Atmosphere Model (CAM 5.0). NCAR Tech. Note NCAR/TN$486+$ STR.

Nobre, P., Siqueira, L.S.P., Almeida, R.A.F., Malagutti, M., Giarolla, E., Castelão, G.P., Bottino, M., Kubota, P., Figueroa, S.N., Costa, M.C., Baptista, M., Irber, I., Marcondes, G.G., 2013. Climate simulation and change in the Brazilian climate model. J. Clim. 26, 6716-6732. http://dx.doi.org/10.1175/JCLI-D-12-00580.1.

O'Donnell, D., Tsigaridis, K., Feichter, J., 2011. Estimating the direct and indirect effects of secondary organic aerosols using ECHAM5-HAM. Atmos. Chem. Phys. 11, 8635-8659. http://dx.doi.org/10.5194/acp-11-8635-2011.

Oliveira, P.H.F., Artaxo, P., Pires, C., de Lucca, S., Procópio, A., Holben, B., Schafer, J., Cardoso, L.F., Wofsy, S., Rocha, H.R., 2007. The effects of biomass burning aerosols and clouds on the $\mathrm{CO}_{2}$ flux in Amazonia. Tellus B 59B, 338-349. http:// dx.doi.org/10.1111/j.1600-0889.2007.00270.x.

Platnick, S., King, M.D., Ackerman, S.A., Menzel, W.P., Baum, B.A., Riedi, J.C. Frey, R.A., 2003. The MODIS cloud products: algorithms and examples from Terra. IEEE Trans. Geosci. Remote Sens. 41, 459-473. http://dx.doi.org/10.1109/ TGRS.2002.808301.

Procópio, A.S., Artaxo, P., 2003. Fires cool amazonia. Fapesp Res. 33.

Ramanathan, V., Chung, C., Kim, D., Bettge, T., Buja, L., Kiehl, J.T., Washington, W.M. Fu, Q., Sikka, D.R., Wild, M., 2005. Atmospheric brown clouds: impacts on South Asian climate and hydrological cycle. Proc. Natl. Acad. Sci. U. S. A. 102 (15) 5326-5333. http://dx.doi.org/10.1073/pnas.050065610.

Rosenfeld, D., Lohmann, U., Raga, G.B., Dowd, C.D.O., Kulmala, M., Fuzzi, S., Reissell, A., Andreae, M.O., 2008. Flood or drought: how do aerosols affect precipitation? Science 321, 1309-1313. http://dx.doi.org/10.1126/ science.1160606.

Sanap, S.D., Ayantika, D.C., Pandithurai, G., Niranja, K., 2014. Assessment of the aerosol distribution over Indian subcontinent in CMIP5 models. Atmos. Environ. 87, 123-137. http://dx.doi.org/10.1016/j.atmosenv.2014.01.017.

Santanna, F.B., 2008. Optical Properties Aerosol in the South of Mato Grosso Dissertation (Master). Physical and Environmental, Physics Department, Federal University of Mato Grosso, UFMT), Cuiabá.

Silva, F.R., Santos, U.P., Saldiva, P.H.N., Lourenco, L.F.A., Miraglia, S.G.K., 2012. Health risks and economic costs of absenteeism due to air pollution in Sao Paulo. Braz. Aerosol Air Qual. Res. 12, 826-833. http://dx.doi.org/10.4209/aaqr.2011.12.0235.

Smirnov, A., Holben, B.N., Eck, T.F., Dubovik, O., Slutsker, I., 2000. Cloud screening and quality control algorithms for the AERONET database. Remote Sens. Environ. 73, 337-349. http://dx.doi.org/10.1016/S0034-4257(00)00109-7.

Stevens, B., Giorgetta, M., Esch, M., Mauritsen, T., Crueger, T., Rast, S., Salzmann, M. Schmidt, H., Bader, J., Block, K., Brokopf, R., Fast, I., Kinne, S., Kornblueh, L., Lohmann, U., Pincus, R., Reichler, T., Roeckner, E., 2013. Atmospheric component of the MPI-m Earth system model: ECHAM6. J. Adv. Model. Earth Syst. 5 http:// dx.doi.org/10.1002/jame.20015.

Stier, P., Feichter, J., Kinne, S., Kloster, S., Vignati, E., Wilson, J., Ganzeveld, L., Tegen, I. Werner, M., Balkanski, Y., Schulz, M., Boucher, O., Minikin, A., Petzold, A., 2005. The aerosol-climate model ECHAM5-HAM. Atmos. Chem. Phys. 5, 1125-1156. http://dx.doi.org/10.5194/acp-5-1125-2005.

Stier, P., Seinfeld, J.H., Kinne, S., Boucher, O., 2007. Aerosol absorption and radiative forcing. Atmos. Chem. Phys. 7, 5237-5261. http://dx.doi.org/10.5194/acp-75237-2007.

Ynoue, R.Y., Andrade, M.F., 2004. Size-resolved mass balance of aerosol particles over the São Paulo Metropolitan area of Brazil. Aerosol Sci. Tech. 38, 52-62. http://dx.doi.org/10.1080/02786820490466756.

Zhang, K., O'Donnell, D., Kazil, J., Stier, P., Kinne, S., Lohmann, U., Ferrachat, S., Croft, B., Quaas, J., Wan, H., Rast, S., Feichter, J., 2012. The global aerosol-climate model ECHAM-HAM, version 2: sensitivity to improvements in process representations. Atmos. Chem. Phys. 12, 8911-8949. http://dx.doi.org/10.5194/ACP12-8911-2012. 